DOI https://doi.org/10.36059/978-966-397-116-2/64-84

\title{
FINANCING POLITICAL PARTIES IN THE WORLD AS A FACTOR OF MINIMIZING CORRUPTION
}

\section{Busol O. Yu.}

\section{INTRODUCTION}

In the whole world it is a well-known fact proved by scientists that corruption can accompany the process of financing political parties. This is exactly why the problem of financing elections campaigns is relevant not only in Ukraine, but also in the political life of all developed countries.

According to the National agency of preventing corruption, the amount for the state funding of parties in Ukraine in 2018 was 513 million 671 thousand $\mathrm{UAH}^{1}{ }^{1}$ At the same time, the results of the public survey conducted by the «Democratic initiatives» Foundation and the Ukrainian Center for Economic and Political studies named after Oleksandr Razumkov show that Ukrainians are not ready to finance political parties at the expense of the state's budget. Thus, $76 \%$ of Ukrainians do not support the idea of financing political parties from the State Budget and $40 \%$ of Ukrainians believe that financing the parties is the task of the party's leaders and party members. Only $13 \%$ of Ukrainians believe that political parties should be financed by the state, and $14 \%$ believe that businessmen should finance them. The Director of the «Democratic Initiatives» Foundation named after Ilko Kucheriv and I. Bekeshkina notes that society has a low-level of trust towards parties because they defend the interest of financial-economic leaders instead of defending the interest of people. This means that the same oligarch must finance his own party $^{2}$. As usual, businessmen, who invest in political parties, expect to gain profit from them. In Ukraine this business could earn profit due to assignment of its protégés to the top positions in the Cabinet of Ministers of Ukraine, The Security service of Ukraine, the General Prosecutor's

\footnotetext{
${ }^{1}$ НАЗК: 513 млн 671 тис. гривень отримають 6 політичних партій на фінансування статутної діяльності на 2018 рік. URL: https://nazk.gov.ua/news/nazk-513-mln-671-tys-gryven-otrymayut-6politychnyh-partiy-na-finansuvannya-statutnoyi.

2 Публичные дебаты. Финансирование политических партий: как избавиться от влияния олигархов. URL: https://www.ukrinform.ru/rubric-presshall/1933013-publichnyie-debatyi-finansirovanie-politicheskihpartiy-kak-izbavitsya-ot-vliyaniya-oligarhov-zal-1.html.
} 
Office of Ukraine and the Ministry of Internal Affairs of Ukraine, judicial agencies, etc. that are used in illegal ways. However, does the tendency when «big businesses» finance political parties have any negative effect?

\section{The Use of Large Business-Groups and Oligarch's Funds to Maintain Political Parties}

In general, the problem of financing political parties should not be considered only in the form of state funding, but also in the form of using the funds from large business groups and oligarchs for maintaining political parties. The state funding that does not belong to any of the government's branches is redistributed within the state's budget and is provided in a transparent way. This practice was used for the first time in Germany and spread to other European Union countries in order to grant independence to parties from the authorities, big businesses and oligarchs, who have the resources to finance politics. Often parties can not refuse these resources because they do not know how to get them from citizens like it is done in the USA, where any pre-election campaign starts with fundraising, as well as for election's agitation ${ }^{3}$.

The ability to finance political parties by big businesses is a specialty of the USA politic system functioning. A good example of this is a list in Forbes, which revealed the main sponsors of B. Obama and M. Romney in the USA pre-election presidential campaign. This information is also available in free access on the Internet ${ }^{4}$. Thus, Hollywood producer S. Spielberg, who is in the Forbes list of 400 richest Americans, has supported B. Obama by donating him 100000 dollars through Priorities USA Action - an independent organization which was created to raise funds for the presidential election. Brothers multimillionaires Charles and David Koch, the founders of the ultraconservative «Tea Party Movement», were raising funds for M. Romney's campaign and were planning to raise 400 million dollars. Both Charles and David Koch have contributed to this campaign themselves by donating 40 and 20 million dollars. A well-known investor W. Buffett (number 2 in the Forbes list) donated a maximum of 38500 dollars to the official re-election campaign of B. Obama and he did not operate through the Priorities USA Action

\footnotetext{
3 Кривцун Д. Чи реальне державне фінансування партій? URL: https://day.kyiv.ua/uk/article/ podrobyci/chy-realne-derzhavne-finansuvannya-partiy.

4 А як у них? Фінансування виборчих кампаній політичних партій. URL: https://rada.oporaua.org/ analityka/a-iak-u-nykh/14030-a-iak-u-nykh-finansuvannia-vyborchykh-kampanii-politychnykh-partii.
} 
organization which was created to support the president. S. Adelson, who is a billionaire and the head of the Las Vegas Sands Empire of casinos, is one of M. Romney's main donator, he and his wife has donated at least 35 million dollars to support of M. Romney. Millionaire P. Pritzker, who is the owner of Hyatt hotels, has been the head of B. Obama's support campaign and has raised more than 100000 dollars for his le-electing campaign. G. Soros had been supporting Obama since 2004, when he stood for the Illinois election campaign and donated 175000 to him. An Israeli-American media magnate $\mathrm{H}$. Saban donated 1 million dollars through the Priorities USA Action organization to support B. Obama. The Manager of New York Hedge Foundation Elliot Management P. Singer raised 5 million dollars to support $M$. Romney and sponsored his campaign by donating 1 million dollars. The financial market legend D. Robertson, the founder of the investment company Tiger Management Corp supported M. Romney by donating 1.3 million dollars.

In the United States of America, it is not only the election headquarters that can start supporting campaigns of a particular candidate, but party organizations and the political action committees (PACs) could also agitate for them. Such committees can conduct an independent political agitation from the candidate, they do not report about their funds, and they can be sponsored by big businesses. PACs gained full autonomy after McCain-Feingold's law about the restriction of the corporation's rights during the pre-election period was considered non-constitutional, and the Judges of the Supreme Court came to the conclusion that the prohibition to finance the political parties' propaganda was a direct violation of the liberty of speech. The so-called case of Citizens United in accordance with the appeal of the PACs caused a huge stream of donations from the big business. This money went to both traditional PACS and the super PACs; it also went to non-governmental organizations, which do not need to report about the donations that they get. The Appeal Court of USA refused to cancel the decision of the federal judge, which obliges non-governmental financial organizations, which use the preferential tax regime but still continue to conduct political agitation live on TV to disclose the sources of their financing. F. Wertheimer, the chairman of the liberal group «Democracy-21» has called this the first major breakthrough in the fight against large-scaled secret inflows, which have filled the federal elections. 
Those who defend the rights of non-commercial organization to hide their sources of income, still have the argument about violating the liberty of speech. It is also noted that those who donate money could face various problems if their generosity is revealed to their political opponents who are currently in power. At the same time, the Supreme Court always defends the transparent policy, which requires the political life participants to disclose the sources of their income, just like in the «Citizen United case» ${ }^{5}$.

Large corporations do not limit themselves to financing only one candidate. Their lobbyists work with both republicans and democrats because the big business wants to have an influence on the politics regardless of who is currently in power. For example, businessman G. Soros has donated 6 million dollars to Hillary Clinton's super committee. Super-committee democrats criticize such actions, but they do not refuse to take the donations during their election campaigns. For example, the USA Priorities Action Foundation which was given to $\mathrm{H}$. Clinton as an inheritance from the ex-president collected more than 100 million dollars in at that time. H. Clinton explains that refusing the help of super-committees means giving the republicans more financial opportunities. She also promised that if she would win the presidential election and take the president's position, she would appoint such judges to the court that would cancel the decision about super-committees. On the other hand, she and D. Trump both had a couple of foundations that were independently raising and spending large amounts of money "for" or "against" these two candidates.

All donations to super-committees are recorded by the Federal Election Commission; the anonymity of money provision is excluded. But there is a loophole; the 501 organizations are non-commercial institutions that have the rights to spend half of the raised funds on politics, while not revealing who their donators are. Therefore, sponsors use this method to support a political candidate while not revealing their participation in a political process ${ }^{6}$.

The activities of political parties do not exhaust the entire specter of forces and organizations that operate on the political arena. The

\footnotetext{
5 Кто финансирует предвыборную кампанию Барака Обамы. URL: https://delo.ua/world/ktofinansiruet-predvybornuju-kampaniju-baraka-obamy-177904/.

${ }^{6}$ 6. Дорогі політики: хто і як фінансує вибори в США. URL: http://ukr.segodnya.ua/economics/enews/ dorogie-politiki-kto-i-kak-finansiruet-vybory-v-ssha-741490.html.
} 
representatives of the entrepreneur circle organize various associations of entrepreneurs to protect their economical and political interests. Nowadays, the constitutions and the legislations of foreign states are regulating various aspects entrepreneurial activity and consolidating the status of business organizations, unions and associations.

The first entrepreneur organization was founded in the United States in 1895. Now they are founded at local, regional and national levels in a form of commercial and industry chambers, associations of employers, branch associations and the national industrial unions, wholesale trading and banking. A good example of this is the Confederation of British Industry, The National Council of French Entrepreneurs, and The Federal Association of national employer unions, The US Business Roundtable, which brings together the representatives of the US financial circles and etc.

Entrepreneurial organization are powerful and influential associations, which have offices with a large number of economists, lawyers, sociologists, psychologists in the field of business, marketing and etc., their apparatus is much bigger than the political parties' staff. The main directions of the entrepreneur association (organizations, chambers and unions) work are: a) the agreement about the economic politics of organizations and the field of economics in general $b$ ) the influence on the relations between wage laborers and entrepreneurs through the development of a certain policy about paying for labor, through solving the problem of unemployment, and the redistribution and retraining of workers, etc. c) the initiation of TNC creation;

d) the influence on the legislation process, preparation and the acceptance of the budget, tax and customs policy; e) the development of personnel policy for the state apparatus, political parties and trade unions; e) the financing of political parties; f) the financing of ideological theories, which are the basis of party programs and election platforms, etc.

By supporting certain political parties, entrepreneurial structures act as so-called curators; follow their activities and political courses. In conclusion, political parties openly follow entrepreneurial organizations recommendation. Unlike political parties whose social composition is heterogeneous, entrepreneurial organizations are specific, closed unions of big entrepreneurs, which are created on a non-party basis. It is them who decide which political party should be financed or supported. Thus, political parties are indirect organizers of entrepreneurial circles, and 
entrepreneurial organizations are the direct organizers. If political parties intensify their activities in the conditions of preparing and conducting election campaigns, then entrepreneurial organizations are constantly working in intense conditions. The spectrum of problems and interests solved by them is extremely huge.

Speaking about ways of entrepreneurs' influence on the state policy, we should mention their direct involvement in the work of the electing agencies as well as the use of services of various lobbying organizations and individual lobbyists ${ }^{7}$.

Although there was a tendency to reduce the financing of parties by businesses in Germany, such practice still remains. There are the following unities among the supporters of the Christian-Democratic Union of Germany (CDU) - the Union of Chemical Industry and the Daimler Automobile concern, which donated 100 thousand Euros each in July of 2013. The Berenberg Bank and three unnamed individuals also contributed by donating significant amounts. Traditionally, Daimler shares money equally between the biggest political parties of Germany. In 2013, before the elections the Social-Democratic Party of Germany (SDPN) also received 100 thousand Euros from the giant of the automobile business. BMW's concern also makes financial investments in different political parties. Their political preferences are quite obvious: the Christian-Social union got 144 thousand Euros, the social-democrats got 107 thousand, and 70 thousand went to the Free Democratic party of Germany (VDPN). Following the CDU about donation amounts are social-democrats, who got 287 thousand Euros at the start of the year. Except auto giants like BMW and Daimler, there was another one big sponsor, whose name is not revealed. FDPG received 129 thousand Euros. The party was supported by the union of Metal-processing and electroindustrialization of earth North Rhine-Westphalia and BMW.

However, in the recent years, according to Spiegel Online, the amounts of donations from big business are constantly decreasing. For example, in 2012 big companies donated 1.3 million Euros, which is three times less than in 2011. In 2010 German political parties received almost four million Euros, and in 2009, which was the election year they received almost six million Euros. However, experts speak about the «drying of the sponsors' stream» of political German parties. According to Spiegel

\footnotetext{
${ }^{7}$ Конституційне право зарубіжних країн. URL: http://alldok.ru/book_536_page_29.
} 
Online, the sponsorship crisis happened due to the range of scandals in the recent years. Nowadays, the society is much more critical to the financial support of politics after president C. Wulff retired from his presidential position in 2012 because he obtained certain privileges from the businessman. Maybe the «Mövenpick scandal» had even a bigger impact on sponsoring. In 2009, which was the election year, the Free Democratic Party received donations in the amount of one million Euros from the hotel network Mövenpick. This became an informational bomb of slowmoving action: democrats acknowledged of this donation when they already achieved the reduction of taxes added to the value of hotel business. Soon after the FDP became known as the «hotel» party and gained the undisguised interest of lobbyist from lots of separate businessinterest ${ }^{8}$.

According to the executive director of the «Transparency of Georgia» E. Gigauri in 2012 (except for August and September) 6 political parties in Georgia included in the election coalition «Georgian dream» received a total of 4607 000, the Unified National Movement - 13 million 43400, the Christian-Democratic movement has received 96100 and the Labor Party has received 337000 lari. The biggest source of income for the political parties is the state's funding and donations. In 2012, donations to the political parties were only provided by individuals, because it was illegal to receive donations from legal entities. E. Gigauri has mentioned that "Nevertheless, based on the analysis of the data that is available for us, it was revealed that 397 sponsors of the Unified National Movement, 33 sponsors of the "Georgian dream", and up to ten sponsors of other political associations were somehow connected to business".

There are clear examples of this in the report. Thus, two representatives from one of the constructional companies «Modernhaus» - have donated 117000 lari to the Unified National Movement. A partner of «Liberty Holding Georgia» V. Gurgenidze and the partner of the affiliated company «Tegeta Motors» T. Kohodze donated 60000 lari to each of the former ruling teams. The same amount was donated to the Unified National Movement by the owner of «Goodwill» Supermarkets - E. Chhaberidze?

\footnotetext{
${ }^{8}$ Німецький бізнес скорочує фінансування партій. URL: http://www.zakonoproekt.org.ua/nimetsjkyjbiznes-skorochuje-finansuvannya-partij.aspx.

9 Финансирование политики бизнесом всегда связано с риском коррупции - TIG. URL: http://www.apsny.ge/2013/pol/1365885061.php.
} 
At same the time where the above-mentioned states allow the financing of political parties by big business, thing are different in other countries - for example, in Latvia, there is an on-going active countering of political crimes. The head of the department for monitoring the financing of political parties of the Bureau of Countering Corruption (KNAB) of Latvia I. Yaunskunga has stated that the Latvian system of monitoring the financing of political parties is one of the best ones in Europe. At the end of $2016 \mathrm{KNAB}$ workers filed a criminal investigation about the violations of law in the field of financing of the political parties. The main suspect was the mayor of Jurmala G. Truksnisa (the Union of «Greens» and peasants», millionaire Y. Kruminsh has been arrested, head of the Kurzeme District Court of the Riga City A. Ornitsya and the financier Y. Raytums were dismissed from their positions, and a rummage was conducted in the Bureau of I. Sudraba's political party «From the heart of Latvia». The former president of Latvia A. Berzinsh, and also the head of the parliamentary fraction of the union of «Greens» and peasants A.Brigmanis ${ }^{10}$ were also noted in the framework of this criminal case.

It is also noteworthy that despite the fact of KNAB's effective work, political scientists state that the country is governed by individuals who have large amounts of money. This leads us to a thought that not everything is going so smoothly in the field of financing political parties in Latvia, as the government says.

According to F. Rajewski the flow of money in politics must be restricted: «It is very important to understand who is influencing the politics because money is the most direct instrument of influence on political parties. Those who earn money are influencing it; those, who are interested in legislative changes; those, who are interested in public procurements. Well, everything is clear: there is a redistribution of the state recourses with the help of political parties, which are the instruments for these redistributions. This is basically the fundamental truth that can be found in any book about politics". F. Rajewski believes that it is practically impossible to protect political parties from money, but it is possible to restrict their expenses. That means that «rinsing the minds of voters before the election, conducting massive election campaigns, which have no content except beautiful pictures and charming tales about good

\footnotetext{
${ }^{10}$ У Латвії до незаконного фінансування партій міг бути причетний екс-президент - 3MI. URL : http://1news.com.ua/svit/y-latv\%D1\%96\%D1\%97-do-nezakonnogo-f\%D1\%96nansyvannia-part\%D1\%96im\%D1\%96g-byti-prichetnii-eks-prezident-zm\%D1\%96.html.
} 
politicians on the television. Thus, the influence of personal capital of third-person parties on lawmaking and other aspects of Latvia's political life could be reduced". As stated above, certain successes in this area already exist in the $\mathrm{KNAB}^{11}$.

The experience of the last parliamentary elections in Latvia, when there was no limitations of spending on the last election campaign, political parties spent around 9 euro per each voter (the biggest amount among all European countries) which indicates that the victory of one or another political force in the election is indicated by the amounts of money spent on pre-election agitation and political commercials on the television $^{12}$.

Continuing the thesis of the successes of foreign countries against overcoming corruption, we should note that on April 3, 2015, the richest man in Romania billionaire I. Niculae was sentenced to two years and six month in prison for illegal financing of one of the candidates of the presidential election in 2009, M. Joanne.

According to the data of the investigation, a former functionary of the Social Democratic Party (PSD) of Romania B. Stanku received one million Euros from I. Niculae for the pre-election campaign of the PSD'S leader M. Joanne, resulted in his loss at the presidential election to T. Bessesk. In exchange for financial support, if M. Joanne had won the presidential election he would have appointed people close to I. Niculae in the Ministry of Economy to lobby businessman's projects. In addition, B. Stanku was also sentenced to three years in prison.

Romanians achieved success in the fight against political corruption due to these three factors:

- The existence of norms in the legislation, which increased the transparency and the accountability of the profit controlling agencies and expenditures of political parties and their candidates during their preelection campaigns;

- The existence of independent criminal agencies and accordingly the existence of investigators, prosecutors and judges;

\footnotetext{
11 Андреев А., Артёменко В. Политолог призвал ограничить партиям возможности тратить деньги. URL: $\quad$ http://lr4.lsm.lv/lv/raksts/den-za-dnem/politolog-prizval-ogranichit-partijam-vozmozhnosti-tratit-dengi.a $75255 /$

Фінансування політичних партій. URL : http://yuriy-shveda.com.ua/index.php/en/ publicistics/articles/84-finansuvannya-politychnyx-partij.
} 
- The legislation about the state financing of political parties, which provided the tools for law-enforcement agencies and the public to control the incomes and the expenses of political parties.

V. Taran says that the introduction of similar norms into the Ukrainian legislation is, perhaps, the only way to overcome political corruption in Ukraine ${ }^{13}$.

Not so long ago a scandal with the highest political leadership broke out in Chile. During the time of the 2013 election campaign, the Minister of Foreign Affairs E. Munos organized a dinner on a luxurious yacht, to which he invited not only the local rich people, but also several LatinAmerican diplomats. To enter this event you had to pay 1000 dollars, and the money allegedly went to support the future president - a candidate from the Socialist Party M. Bashelle.

The Court of New Zealand has established that the former candidate for the mayor position D. Banks anonymously received 40000 dollars from the founder of the Megaupload site - K. Dotcom. In the bank, $\mathrm{K}$. Dotcom was advised to split his bank account into two separate ones to hide the data about who made the donations. As a result of discovering the financial identity falsification, D. Banks, who was a deputy at the time, had to leave parliamentary position.

Activists from the Czech Republic have created a site where the information about the political party's donors is being constantly published. You could find which oligarchs are very much interested in the politics here in 30 seconds. Moreover, there is information about companies who donate money to parties and then receive profit from the state's procurement procedures.

The "liberal" model in financing election campaigns was established at a legislative level in the early 90's of the twentieth century in the majority of post-socialists states of Europe, it was a model which did not provide any restrictions to financing a political party in the elections. In particular, they did not limit the maximum amount that could be donated to the electoral campaign (the size of the electoral foundation), nor the sources that formed the electoral foundations, nor the donation amounts; there were not any requirements about the need to report the sources of income and where the money was going to be used during the election campaign. This model existed for a long time in Latvia, Lithuania,

\footnotetext{
13 Таран В. 3 чого потрібно починати деолігархізацію України. URL : http://www.pravda.com.ua/ articles/2015/04/9/7064261/view_print/.
} 
Estonia, Bosnia, Croatia, Poland, but the lack of any restrictions about the size of the election foundations turned election campaigns from the conflict of ideologies to the conflict of money ${ }^{14}$.

In general, the rules of financial accountability for parties operate in 125 different countries in the world. The most common way of reducing the influence of big business is the restriction of the maximum amount of yearly or pre-electoral donations. But without an adequate system of control and the effective work of the control agencies, these measures are pointless. Nothing prevents the donators from splitting the amount of their donations into two separate ones and transferring them through forensic individuals. This is why corporative contributions should not be restricted, although that norm has already acted in 40 countries.

A similar issue happens with anonymous donations. They can only be revealed if the donation is conducted through a special banking account. But what about the small donations that the party receives during its election campaigns? Usually this problem is solved through the implementation of a certain barrier below which the anonymity of the donator is preserved.

In both cases it is important not to overestimate the margin so manipulations with artificial splitting of donations have become unbeneficial. This problem is being encountered all around the word, this includes developed countries.

The last, but at the same time the most important issue is the shadow donations. Even if the political party has a transparent bank account and a very low barrier for anonymous donations, it is not certain that all registered donations pass through it. Let's say that during the election campaign political parties get the ability to get discounts on party services, this opens a room for shadow donations. Although, it could be restricted by legislative norms, when services could only be provided at an average market value.

There are other ways such as opening a shadow bank account. This tactics is used all around the world, and it is almost impossible to discover the machinations of political parties this way.

As numerous examples show, transparency systems can not deprive political parties and corrupt politicians from the temptation of getting additional donations regardless if they are legal ${ }^{15}$ or not.

\footnotetext{
${ }^{14}$ Фінансування політичних партій. URL: http://yuriy-shveda.com.ua/index.php/en/publicistics/articles/ 84-finansuvannya-politychnyx-partij.
} 


\section{Peculiarities of Financing Political Parties in Ukraine}

As of today, Ukraine has taken into the account the recommendations of PACE 1516 (2001) «European standards in the field of financing political parties» (In case of violating the legislation, political parties must be subjected to sanctions... When individual liability is established, sanctions must annihilate the mandate and temporary restrict parties from having the right to get certain positions, as well as the recommendations given in the GRECO Assessment Report «The transparency of financing political parties», the third round of evaluation (2011) «....to ensure that all violations of.... the rules of financing political parties and election campaigns were clearly defined and punished with effective, proportionate and dissuasive sanctions; party representatives and candidates should be personally responsible for violating the laws of party financing and electoral campaigns; the limitation periods for these offences would be sufficiently long to allow competent agencies to effectively monitor the financing of political parties». In order to prevent political corruption there is a criminal responsibility for such actions in the Criminal Code of Ukraine, for example, Article 159-1 (Violation of the laws of financing political parties, pre-election agitation, and agitation from the United Ukrainian referendum or the local referendum) and Article 160 (Bribery of a candidate or a referendum participant).

Some Ukrainian politicians are not very optimistic about the state funding of political parties in Ukraine. Thus, V. Lutsenko, a national deputy from the party "United Ukrainian Union of "Motherland" who is now the General Prosecutor of Ukraine does not believe that we can obtain the result from financing political parties that everyone expects. If we split the donated money to the amount of parties that are supposed to be financed, we will get less than 80 million UAH for each one, which means around 3 million dollars. This is the budget of one of the majorelection campaigns, which means the elections of one oligarch on one district. That definitely will not equal the rights of all political parties; it won't become a real support for young and minor parties like «Demalliance» and others. The party's survival in the electoral race is influenced by much smaller expenses. Their main expenses go to media, television channels for example. Sponsorships are usually based on media and not finances. For example, a certain oligarch negotiates with some

15 Лємєнов О., Кучма О. Гроші партій: як залишити олігархів без «політичного таксі». URL : http://www.pravda.com.ua/articles/2015/04/16/7064924/. 
kind of fraction, he lets them to be on his channel for certain benefits, and in exchange, the fraction promises not to vote for a decision that won't be beneficial to the oligarch. All of this work is usually done during the election period to increase the ratings.

As for Majoritarians, they receive a franchise on one or other side of the territory. It means that the candidate should not provide support to the party's brand and actually needs to finance his advertisements himself. This is how the party gets profit from him, and the candidate goes as an influencer from the party. This money is associated with the "shadow" schemes and revealing them is very hard.

Politic scientist V. Fesenko mentions that the financing of political parties in Ukraine is still hidden, so it is almost impossible to evaluate whether sufficient money has been allocated from the budget or not. It should be noted that more and more political parties in the regions are being supported by local sponsors. It is also hard to say what the ideal model of calculation of the state financing should be, and what the minimum of funds needed for the functioning of parties and their needs is. It is quite paradoxically, but the authors of the draft law have taken the experience of counting amounts from Russia. There is 1 billion rubles contributed to these purposes each year in the Russian Federation. It only depends on the political party whether the oligarch's influence on politic parties has reduced or not. We have to be realists here. If the party wants to receive additional profit, they will get it. But then why the state financing of political parties should exist? It is important because it reduces the temptation. It is important so that the parties that don't want to take money from the oligarch's would have an alternative.

Political analysts believe that as the result of implementing the law of state funding the influence of oligarch on political parties will be reduced, but only one law will not be enough. This is a major step forward, but it is far from separating oligarch's relations with political parties ${ }^{16}$.

In Ukraine, if the party overcame the $5 \%$ barrier during the last elections, it will receive financial support from the state. According to the results of the 2019 elections, parties that overcome the $2 \%$ barrier will receive financing. As the coordinator of parliamentary and election programs believes, the state financing in Ukraine could be used as to reassure the transparency of expenses and donations on political party's

\footnotetext{
${ }^{16}$ Середа Е. Госфинансирование партий не уменьшит влияния олигархов на политику, - эксперты. URL : http://hubs.ua/authority/gosfinansirovaniepartij-ne-umen-shit-vliyanie-oligarhov-na-politiku-eksperty89354.html.
} 
bank accounts during the inter-election period and during the elections. At the same time, the parties should be prepared for the audit of their financial activity, adjust their financial flows and their structures. But nowadays the problem is that the political parties aren't interested in doing this. They are satisfied with the unaccountable methods of spending oligarch's money on election campaigns and during the inter-election period. So they do not seek the state funding. It is extra-parliamentary parties or new political forces of European orientation which are interested in such laws ${ }^{17}$.

Ukrainian citizens also do not ignore the problem of financing political parties. Here is an abstract from a critical article from Ukr.media, in which the author allegorically conveys the imperfection of the Ukrainian law about financing political parties and tells everyone not to copy the foreign experience in this problem, from which you could conclude a certain rational kernel: "Just like savages who saw a fancy necklace (heard that the state finances political parties from its budget) and start to run around with it like it's a new purse, without even thinking how that law is going to work in practice. The main channel for avoiding any restrictions about financing campaigns and political parties is shadow financing (and the support) thought the controlled mass media which belongs to the..... oligarch. There isn't a way to control hidden advertisements (through the news for example), because it will be stated to the wise men that we have such editorial policies. Basically, the dependence from the oligarch will increase drastically. I am confident that there will be a business soon where a network of people is going to be built, a network which is going to constantly donate something for someone while not violating the law. .... The pittance that the state is donating to the financing of the campaign could not even be compared with the budget that the business and the lobbying of interest are going to give them. The most important thing here is to implement the law about "lobbying", which will somehow regulate this market and make it transparent, because its main goal is based on normal and rational logic politicians will always use their position» ${ }^{18}$.

For the sake of objectivity, we should quote the thoughts of average citizens about this problem, stated in the petitions. Thus, this is what the

\footnotetext{
17 Кривцун Д. Чи реальне державне фінансування партій? URL: https://day.kyiv.ua/uk/article/ podrobyci/chy-realne-derzhavne-finansuvannya-partiy.

${ }^{18}$ Чому олігархи лопнуть від сміху від нового закону про фінансування українських партій. URL: https://ukr.media/politics/244904/.
} 
Ukrainian citizen suggests (taken from the petition's text): "When the authorities comply with the West's requirements about the financing of political parties by the citizens of the state then it is necessary to make some corrections in this law, which prohibits financing without ideology, without the democracy of business-political projects, which are registered for the elections and also for parties registered for one individual. If we accept the financing of political parties by the citizens, it would be fair if the citizens finance the political parties themselves and not businesspolitical projects, with their political ideology and democracy, which at the beginning of the 90s were fighting for Ukrainian interests and independence, while not stealing anything from Ukraine» ${ }^{19}$. Interesting propositions are outlined in the Russian Federation in a petition which suggests perfecting the state financing of political parties through the method of taxes, which would stimulate donations to the supporters of political parties. It is economically unprofitable for a worker to join an independent politic party from the business money and oligarchs. Regarding the financing of political parties by commercial companies (legal entities), they seek to receive direct or indirect benefits like lobbying the interest of some certain company, or gaining the deputy's immunity. In this case the party mostly works for the business and not for the workers. The author of the petition suggests letting individuals to yearly donate a certain amount from their paid taxes for the last year on the bank account of the political party that they support through the private taxpayer's cabinet. This will reduce the financial dependence from the investors, whose interest is being lobbying by the forced parties, which causes losses to the most of their civilian supporters.

Such financing does not cancel the already implemented laws about the state's financing; it only reduces the planned amount of money, which is allocated to political parties proportionally to the amount that the citizens have contributed through their personal taxpayer's cabinets. Which result is expected from the suggested innovation? The most productive and useful political parties will receive more money, the support of the citizens, and more chances to take the authorities position, and the ineffective ones will have to re-consider their campaigns. This stimulates the parties to execute their pre-election promises to the voters. On the other hand, the voters could limit party's financing due to the laws

\footnotetext{
19 Швець І. В. Заборонити фінансування з кишень українських громадян так званих політичних партій, бізнес- проектів під одну особу-олігарха. URL: https://petition.president.gov.ua/petition/15769.
} 
that clearly include corruption, that were adopted by the party ${ }^{20}$ in the future.

According to the authors studying non-governmental organization of Georgia, the financing of politics by business is always associated with the risk of corruption. That is why a proper regulation of donations is needed. On the other hand, a complete prohibition of donations from the legal entities causes unjustified and disproportionate restriction of their constitutional rights of freedom and expression of their political activity. The report highlighted the fact that there isn't a single document which has been developed by a certain international organization about Georgia, which would suggest a complete restriction for financing political parties by the legal entities. The authors believe that instead of a complete prohibition to financing political parties by the legal entities, certain regulating norms should be implemented to avoid already existing risks ${ }^{21}$.

One of the political parties in Ukraine has suggested another scheme for the interaction of state and the business as a basis to form a new social politics of the state. According to its ideology, the dialogue between them will develop when both sides accept their obligations. Each sector should define its field of responsibility. There should be no situations where the authority agencies will force business to donate money for social projects. A certain quote applies to business as well as too all of us: "Living in a society while being free from the society is impossible". But even to this day the national business is not fully aware of the fact that the decisions of long-lasting and short-lasting business objectives are tied with the tendencies of the development of society as a whole. The priorities of all forms of business shouldn't just change; they should expand their narrow temporary boundaries. The emphasis on receiving the maximum profit should be gradually replaced by the realization that the focus on the socially-responsible business is the key to future growth of the company, its employees and the whole society. That way socially-responsible business, and the goals and objectives of the project could be realized only in a narrow space of combining the interest and the priorities of three groups - the business itself, the state and the society. We are talking about such social changes that could lead to a convergence of these interests ${ }^{22}$.

\footnotetext{
20 Усовершенствовать государственное финансирование политических партий через налоговые методы, стимулирующие пожертвования сторонникам партий. URL: https://www.roi.ru/25422/.

21 Финансирование политики бизнесом всегда связано с риском коррупции - TIG. : URL: http://www.apsny.ge/2013/pol/1365885061.php.

${ }^{22}$ Новая філософія бізнеса. URL: http://www.narodnadovira.org/p/blog-page_29.html.
} 
This concept have something in common with the conclusion of criminologist Y. Orvol that the strategic principles of relations between the state and large businesses should include neither confrontation, nor the attempts to clear the authorities from the oligarch's influence, they should include the cooperation with the further elimination of criminal forms of activity in the field of politics ${ }^{23}$.

There is an opinion that the financing of political parties by the business representatives is beneficial not only to the political parties, but also to the state because when the national financing takes place there will be no attempts and desire to find means for work elsewhere, including somewhere abroad. This is basically how it happens all around the world: people finance political parties because of their political beliefs, and opinions, and that's how they finance their future. They finance the economical and social campaigns which are beneficial for them; they support different political parties which contribute to the promotion of their opinions and ideas. Belarusian politics mention that: "It doesn't matter which statement and actions are made by the authorities, business is the only thing that helps us, people help us", «if there are mechanism for this, but unfortunately all of this what happens causes damage to the national interest and to the development of the political system, which is bad to the economic development and the country's ${ }^{24}$ development in general»».

It should be taken into the account that there are no oligarchs in the EU that we know in the Ukrainian sense. There are only big businesses, which pay taxes and do not affect the politics directly. The society must learn to see the difference between big business which honestly pays taxes and oligarchs who get rich from monopolies, corruption schemes and the access to the state-owned enterprises, between the freedom of speech and the fake information by the bribed mass media, between true patriots and the playing politics, who protect their sponsors $^{25}$ by shouting patriotic slogans.

\footnotetext{
${ }^{23}$ Орлов Ю. В. Політико-кримінологічна теорія протидії злочинності : дис. ... д-ра юрид. наук : 12.00.08. Орлов Юрій Володимирович. Харків., 2016. С. 375.

${ }^{24}$ Финансирование бизнесом политических партий: за и против. URL: http://www.interfax.by/news/ belarus/1125935.

${ }^{25}$ Шокотерапія для олігархів. URL: http://archive.volyn.com.ua/printver.php?rub= 4\&article=0\&arch= 1803.
} 


\section{CONCLUSIONS}

An analysis of the political party's activities in countries makes it possible to draw the following conclusions: a) political parties that are deeply integrated into the state's political mechanism have a much larger influence on the social-economical and political processes, that happen in the society; b) the conclusions about the party's activity shouldn't be based on its name, activity, pre-election platform or the popular slogans, that it uses during the election campaign, but on specific actions that the party makes when it takes the authorities position, works in the state's structures on a coalition basis or as an opposition party.

The lack of legislative limits of expenses and the donations to the election campaign, the requirements to reveal the information about the sources of the election foundation formation, which leads to the increase of the corporations influence on the party's finances, which means the corruption of the politics, but on the other hand - it does not give a basis to reveal which financial-industrial groups are behind the victory of a political party on the elections. All of this makes it necessary to implement restrictions about financing election campaigns ${ }^{26}$.

The financing of political parties by big business should only be implemented only under the conditions of the process transparency, and the possibilities of controlling it from the citizens' side. Large businessman, millionaires are people with a commercial streak, strong leaders, excellent managers who have the right connections and acquaintances, which strongly help them to organize efficiently and correctly almost any case. This is why the state should not deny the financing of political parties by big business, but rather cooperate to receive equal benefits for both sides.

Analyzing the foreign experience and Ukrainian realities the new trends for the formation of a new philosophy of political party financing in Ukraine by big businesses can be seen based on mutual cooperation of large private corporations and the state as well as transparent and fair grounds. This way is the only factor of reducing corruption in the world.

\section{SUMMARY}

It is a well-known fact proved by scientists that corruption can accompany the process of financing political parties. This is exactly why

\footnotetext{
${ }^{26}$ Фінансування політичних партій. URL: http://yuriy-shveda.com.ua/index.php/en/publicistics/articles/ 84-finansuvannya-politychnyx-partij
} 
the problem of financing elections campaigns in relevant not only in Ukraine, but also in the political life of all developed countries.

Usually businessmen who invest in political parties expect to gain profit from them. In Ukraine this business could earn profit due to assignment of its protégés to the top positions in the Cabinet of Ministers of Ukraine, The Security service of Ukraine, the General Prosecutor's office of Ukraine and the Ministry of Internal Affairs of Ukraine, judicial agencies, etc. that use illegal ways. However, does the tendency of «big businesses» financing political parties have any negative effect? In general, the problem of financing political parties shouldn't be seen only in the form of state funding, but also in the form of using the funds from large business groups and oligarchs for maintaining political parties An analysis of the political party's activities in foreign countries makes it possible to draw the following conclusions: a) political parties that are deeply integrated into the state's political mechanism have a much larger influence on the social-economical and political processes, that happen in the society; b) the conclusions about the party's activity shouldn't be based on its name, activity, pre-election platform or the popular slogans, that it uses during the election campaign, but on specific actions that the party makes when it takes the authorities position, works in the state's structures on a coalition basis or as an opposition party. The financing of political parties by big business should only be implemented if the conditions of the process transparency are met, and the possibilities of controlling it from the citizens' side. Large businessman, millionaires are people with a commercial streak, strong leaders, excellent managers who have the right connections and acquaintances, which strongly help them to organize efficiently and correctly almost any case. This is why the state should not deny the financing of political parties by big business, but rather cooperate to receive equal benefits for both sides. Considering foreign experiences and Ukrainian realities, one can observe the tendencies towards the formation of the new philosophy of financing political parties in Ukraine by the big business, based on the cooperation from large private corporations and the state on transparent and fair grounds. This is one of the ways to minimize corruption.

\section{REFERENCES}

1. НАЗК: 513 млн 671 тис. гривень отримають 6 політичних партій на фінансування статутної діяльності на 2018 рік. URL: 
https://nazk.gov.ua/news/nazk-513-mln-671-tys-gryven-otrymayut-6politychnyh-partiy-na-finansuvannya-statutnoyi.

2. Публичные дебаты. Финансирование политических партий: как избавиться от влияния олигархов. URL: https://www.ukrinform.ru/ rubric-presshall/1933013-publichnyie-debatyi-finansirovaniepoliticheskih-partiy-kak-izbavitsya-ot-vliyaniya-oligarhov-zal-1.html.

3. Кривцун Д. Чи реальне державне фінансування партій? URL: https://day.kyiv.ua/uk/article/podrobyci/chy-realne-derzhavnefinansuvannya-partiy.

4. А як у них? Фінансування виборчих кампаній політичних партій. URL: https://rada.oporaua.org/analityka/a-iak-u-nykh/14030-aiak-u-nykh-finansuvannia-vyborchykh-kampanii-politychnykh-partii.

5. Кто финансирует предвыборную кампанию Барака Обамы. URL: https://delo.ua/world/kto-finansiruet-predvybornuju-kampanijubaraka-obamy-177904/.

6. Дорогі політики: хто і як фінансує вибори в CШA. URL: http://ukr.segodnya.ua/economics/enews/dorogie-politiki-kto-i-kakfinansiruet-vybory-v-ssha-741490.html.

7. Конституційне право зарубіжних країн. URL: http://alldok.ru/book_536_page_29.

8. Німецький бізнес скорочує фінансування партій. URL: http://www.zakonoproekt.org.ua/nimetsjkyj-biznes-skorochujefinansuvannya-partij.aspx.

9. Финансирование политики бизнесом всегда связано с риском коррупции - TIG. URL :http://www.apsny.ge/2013/pol/1365885061.php.

10. У Латвії до незаконного фінансування партій міг бути причетний екс-президент - 3MI. URL : http://1 news.com.ua/svit/ylatv\%D1\%96\%D1\%97-do-nezakonnogo-f\%D1\%96nansyvanniapart\%D1\%96i-m\%D1\%96g-byti-prichetnii-eks-prezidentzm\%D1\%96.html.

11. Андреев А., Артёменко В. Политолог призвал ограничить партиям возможности тратить деньги. URL: http://lr4.lsm.lv/lv/ raksts/den-za-dnem/politolog-prizval-ogranichit-partijam-vozmozhnostitratit-dengi.a75255/.

12. Фінансування політичних партій. URL : http://yuriyshveda.com.ua/index.php/en/publicistics/articles/84-finansuvannyapolitychnyx-partij.

13. Таран В. 3 чого потрібно починати деолігархізацію України. URL : http://www.pravda.com.ua/articles/2015/04/9/7064261/view_print/. 
15. Лємєнов О., Кучма О. Гроші партій: як залишити олігархів без «політичного таксі». URL : http://www.pravda.com.ua/ articles/2015/04/16/7064924/.

16. Середа Е. Госфинансирование партий не уменьшит влияния олигархов на политику, - эксперты. URL : http://hubs.ua/authority/ gosfinansirovaniepartij-ne-umen-shit-vliyanie-oligarhov-na-politikueksperty-89354.html.

18. Чому олігархи лопнуть від сміху від нового закону про фінансування українських партій. URL: https://ukr.media/politics/ 244904/.

19. Швець I. В. Заборонити фінансування з кишень українських громадян так званих політичних партій, бізнес- проектів під одну особу-олігарха. URL: https://petition.president.gov.ua/petition/15769.

20. Усовершенствовать государственное финансирование политических партий через налоговые методы, стимулирующие пожертвования сторонникам партий. URL: https://www.roi.ru/25422/.

22. Новая філософія бізнеса. URL: http://www.narodnadovira.org/ p/blog-page_29.html.

23. Орлов Ю. В. Політико-кримінологічна теорія протидії злочинності : дис. ... д-ра юрид. наук : 12.00.08. Орлов Юрій Володимирович. Харків., 2016. С. 375.

24. Финансирование бизнесом политических партий: за и против. URL: http://www.interfax.by/news/belarus/1125935.

25. Шокотерапія для олігархів. URL: http://archive.volyn.com.ua/ printver.php?rub=4\&article $=0 \& \operatorname{arch}=1803$.

\section{Information about author:}

Busol O. Yu.

Doctor of Juridical Sciences, Senior Research Officer, Head of the Department of Special-Legal Disciplines of the Scientific-Training Humanitarian Institute of the V. I. Vernadsky Taurida National University 33, John McCain str., Kyiv, 01042, Ukraine, Chief Researcher of the Interagency Scientific and Research Center on Problems of Combating Organized Crime under the National Security and Defense Council of Ukraine 1, Solomenskaya square, Kyiv, 03035, Ukraine 